\title{
Ghrelin secretion is more closely aligned to energy balance than with feeding behaviour in the grower pig
}

\author{
K Scrimgeour, M J Gresham, L R Giles ${ }^{1}$, P C Thomson, P C Wynn and R E Newman \\ Faculty of Veterinary Science, University of Sydney, Camden, New South Wales 2570, Australia \\ ${ }^{1}$ Department of Primary Industries, Elizabeth Macarthur Agricultural Institute, Camden, New South Wales 2570, Australia \\ (Correspondence should be addressed to R E Newman; Email: ronaldn@camden.usyd.edu.au)
}

\begin{abstract}
Secretory characteristics of the ghrelin profile for the pig are still unknown. Our objective was to clarify the mechanisms that influence ghrelin secretion during differing feeding patterns. Pigs were initially fed a commercial pelleted diet offered ad libitum and blood samples collected for $24 \mathrm{~h}$ at intervals of $1 \mathrm{~h}$. The pigs were then entrained for 17 days to a twice daily interval feeding regimen (0900-1000 and 1600$1700 \mathrm{~h})$ and blood samples were collected for $12 \mathrm{~h}(0800$ $2000 \mathrm{~h}$ ). This was followed by a similar interval feeding and blood sampling regimen with the 0900-1000 h feeding period being replaced by a sham feed where pigs were shown their usual feed but none offered. During the ad libitum feeding regimen, there was no preprandial rise or postprandial fall in circulating plasma total ghrelin concentration, which
\end{abstract}

remained constant throughout the sampling period. In addition, no preprandial rise or postprandial fall in ghrelin concentrations was observed when pigs were fed either twice or once daily; however, plasma ghrelin concentration rose gradually over the 12-h sampling period during the twice daily feeding regimen and increased further when pigs were fed once per day. This increase in ghrelin levels coincided with an increase in plasma GH and non-esterified fatty acid concentrations and was not associated with either plasma glucose or insulin concentrations. These results suggest that circulating total plasma ghrelin concentrations in the pig appear to be influenced by chronic changes in energy balance rather than the feeding pattern per se.

Journal of Endocrinology (2008) 198, 135-145

\section{Introduction}

In most mammals, ghrelin is mainly produced in the mucosa of the stomach fundus, where it is abundant in the oxyntic, pyloric and cardiac glands (Date et al. 2000, Tomasetto et al. 2000, Dornonville de la Cour et al. 2001, Hayashida et al. 2001, Rindi et al. 2002, Govoni et al. 2005). A recent study (Govoni et al. 2005) in pigs has shown that ghrelin is most abundant in the oxyntic and cardiac glands and less numerous in the pyloric glands. Ghrelin has also been discovered in the intestines (decreasing from the duodenum to the colon), pancreas, lungs, kidneys, testis, placenta, immune cells, hypothalamus and pituitary (Peeters 2005). Two-thirds of circulating plasma ghrelin is derived from the stomach and the remaining one-third from the small intestine (Peeters 2005).

Ghrelin has been shown to have numerous physiological functions that affect energy balance (Horvath et al. 2001, Govoni et al. 2005), gastrointestinal motility and secretion (Masuda et al. 2000) and feeding behaviour (Wren et al. 2000). In humans, plasma ghrelin concentrations increase 1-2 h before the onset of each meal and decrease within $1 \mathrm{~h}$ of re-feeding (Cummings et al. 2001). Obese humans tend to have lower circulating levels of ghrelin compared with individuals who are under weight (Tschöp et al. 2001, Shiiya

et al. 2002, Erdmann et al. 2003) while weight loss in obese individuals increases circulating ghrelin status: by contrast, weight gain in humans with anorexia nervosa reduces plasma ghrelin concentrations (Ariyasu et al. 2001, Otto et al. 2001, Erdmann et al. 2003).

A similar finding has also been reported for a ruminant species, the sheep in which the fluctuations in circulating glucose status are buffered by the rumen. In spite of this, Sugino et al. (2002) observed a transient surge in plasma ghrelin levels prior to feeding in restrictively fed sheep, which then declined. In rodents, stomach ghrelin mRNA levels are increased following an extended fast, while re-feeding restores stomach expression values (Lee et al. 2002). These studies have lead to the suggestion that ghrelin functions as a neuropeptide signal that initiates the onset of feeding. However, it is also plausible that the preprandial rise in plasma ghrelin may be a consequence of an anticipatory response to the entrainment to a specific feeding pattern (Drazen et al. 2006). In their study, both fasted rats not anticipating a meal and those fed ad libitum showed no preprandial rise in ghrelin. A similar result has also been observed for ad libitum fed sheep (Sugino et al. 2002).

Ghrelin influences energy homeostasis by providing a peripheral signal that regulates feeding behaviour through the 
activation of neuropeptide Y/Agouti-related peptide neurones in the arcuate nucleus of the hypothalamus (Kamegai et al. 2000, Nakazato et al. 2001, Shintani et al. 2001). The exogenous administration of ghrelin to rats has both orexigenic and adipogenic effects, as it stimulates appetite and reduces fat utilisation (Tschöp et al. 2000). The regulation of the orexigenic nature of ghrelin is subject to both the animal's nutritional status (Ariyasu et al. 2001, Otto et al. 2001, Erdmann et al. 2003) and to the type of macronutrient ingested (Erdmann et al. 2003). Meals rich in carbohydrates consumed by human subjects have a greater suppressive effect on ghrelin levels than meals rich in fats (Erdmann et al. 2003). This effect may be species dependent as no such relationships have been found in the rat (Gomez et al. 2004). Studies using rodents fed ad libitum have shown that ghrelin is expressed in a diurnal pattern with two peaks, one at $1500 \mathrm{~h}$ (during the light period) and the other at $0600 \mathrm{~h}$ (at the end of the dark period). The physiological significance of these two peaks is unknown, although they coincide with the timing of the lowest and the greatest gastric emptying and filling activity, when gastric acid secretion and gastric motility are most apparent (Masuda et al. 2000).

Although ghrelin secretion has been studied in humans, sheep and rodents, only little is known about the effect of feeding behaviour on plasma ghrelin concentration in growing pigs. Porcine ghrelin status responds to changes in energy balance with concentrations increasing in response to fasting (Salfen et al. 2003, Govoni et al. 2005, Inoue et al. 2005). Moreover, exogenous ghrelin given chronically to weanling pigs increases body weight suggesting that ghrelin may also have an influence on feeding behaviour (Salfen et al. 2004). However, the basal secretory characteristics for ghrelin are still unknown for the pig. The objective of this study was to clarify the association between ghrelin secretion, feeding behaviour and changes in energy balance. We tested this association with pigs that were given either voluntary access to feed or entrained to a twice daily feeding regimen and compared the effects of these differing feeding patterns on circulating ghrelin, growth hormone $(\mathrm{GH})$, insulin, glucose and nonesterified fatty acids (NEFA).

\section{Materials and Methods}

\section{Animals and experimental procedures}

Animal care and procedures were approved by the Animal Ethics Committee of the Elizabeth Macarthur Agricultural Institute (EMAI). Ten entire male pigs (large white $X$ landrace), with a live weight of $57.5 \pm 2.9 \mathrm{~kg}$ (mean \pm S.E.M.), were used for this trial. The pigs were transported from the University of Sydney to the controlled environment facility at EMAI, weighed and allocated to individual pens in the same room and maintained at $22 \pm 1{ }^{\circ} \mathrm{C}$ and a $12 \mathrm{~h}$ (0600-1800 h) light regimen. The pigs were habituated to their new environment for 6 days prior to the onset of the trial. During the habituation period, all pigs were fed a pelleted commercial grower diet estimated to contain $13 \mathrm{MJ}$ digestible energy and $6.2 \mathrm{~g}$ available lysine per $\mathrm{kg}$. Feed was offered ad libitum (regimen A) and water was provided using nipple drinkers. Residual feed was collected and recorded each day. On day 7, a catheter was placed into the external jugular vein of each pig via the ear vein (Anderson \& Elsley 1969). On day 8 , blood samples $(3 \mathrm{ml})$ were collected from each pig at intervals of $1 \mathrm{~h}$ for $24 \mathrm{~h}$ and activity for each pig was monitored using near infrared surveillance cameras. The video records were examined to measure time spent lying, standing, sitting and feeding for each pig. On day 9, all pigs were entrained to feed at two feeding periods (0900-1000 h and $1600-1700 \mathrm{~h}$ ) per day (regimen B), a total of $95 \%$ of that consumed in regimen A (Table 1). On day 26, blood samples were collected for $12 \mathrm{~h}(0800-2000 \mathrm{~h})$ at intervals of $1 \mathrm{~h}$ and the pig activity was monitored. On day 27, a similar experimental regimen was used but the first feeding period (0900-1000 h) was replaced by a sham feed where pigs were shown their usual feed but none was offered (referred to subsequently as 'modified regimen B: fed once only').

\section{Feed intake and body weights}

Estimates of daily feed intake for experimental days 3, 4, 5, 6 and 8 were obtained for regimen A by subtracting the daily residue weight from the weight of the feed offered the previous day. Similarly, feed residues collected at 1000 and $1700 \mathrm{~h}$ were subtracted from feed offered at 0900 and $1600 \mathrm{~h}$ respectively during feeding regimen $\mathrm{B}$. To account for any feeding expectation induced by human presence, specific feeding and blood sampling personnel were employed over the duration of the experiment. To minimise any feeding response resulting from familiarity with clothing worn by the feeder, those feeding and those sampling wore different coloured attire. Body weights of the pigs were recorded on days $1,11,19$ and 33 .

\section{Hormone and metabolite analyses}

Ghrelin peptide was extracted from porcine plasma using octadecyl $\mathrm{C}_{18}$ mini columns (Amersham Biosciences) prior to determination by RIA. Total plasma ghrelin concentrations were determined in duplicate using a commercial doubleantibody RIA with a primary antibody raised against porcine ghrelin and ${ }^{125}$ I-labelled ghrelin as the tracer (kit RK-031-52; Phoenix Pharmaceuticals, Belmont, CA, USA). Plasma insulin and $\mathrm{GH}$ concentrations were determined by RIA (Downing et al. 1995). The insulin RIA was a heterologous assay using an anti-ovine insulin antibody raised in guinea pigs, which was used in the assay at a final dilution of 1:120 000. The antibody cross reacted with porcine insulin $(56 \%)$ and pro-insulin (32\%) relative to ovine insulin, but not with $\mathrm{C}$ peptide or glucagon. The reference standards were prepared from purified porcine insulin (Lot \#49110830 
Table 1 Mean ( \pm s.E.M.) plasma concentrations of glucose, NEFA, ghrelin, GH and insulin for pigs fed ad libitum (regimen A), twice daily (regimen B) and once daily (modified regimen B)

\begin{tabular}{|c|c|c|c|c|c|c|}
\hline & Time & Ghrelin (pg/ml) & NEFA $(\mathrm{mEq} / \mathrm{l})$ & Glucose $(\mathrm{mmol} / \mathrm{l})$ & Insulin $(\mathrm{ng} / \mathrm{ml})$ & $\mathbf{G H}(\mathrm{ng} / \mathrm{ml})$ \\
\hline & Day 8 & & & & & \\
\hline All pigs fed ad libitum (feed & $6: 00$ & $129 \cdot 06 \pm 54 \cdot 09$ & $0 \cdot 13 \pm 0 \cdot 03$ & $6 \cdot 56 \pm 0 \cdot 38$ & $0 \cdot 63 \pm 0 \cdot 15$ & $0 \cdot 18 \pm 0 \cdot 06$ \\
\hline remained in trays) & $7: 00$ & $86 \cdot 27 \pm 21 \cdot 46$ & $0 \cdot 08 \pm 0 \cdot 01$ & $6 \cdot 53 \pm 0 \cdot 40$ & $0 \cdot 98 \pm 0 \cdot 14$ & $0 \cdot 18 \pm 0 \cdot 04$ \\
\hline & 8:00 & $58 \cdot 22 \pm 7 \cdot 49$ & $0 \cdot 08 \pm 0 \cdot 01$ & $6 \cdot 30 \pm 0 \cdot 30$ & $0 \cdot 90 \pm 0 \cdot 20$ & $0 \cdot 15 \pm 0.06$ \\
\hline & 9:00 & $56.06 \pm 7.92$ & $0 \cdot 08 \pm 0.01$ & $6 \cdot 10 \pm 0 \cdot 43$ & $0.55 \pm 0.08$ & $0 \cdot 11 \pm 0.03$ \\
\hline & $10: 00$ & $48.63 \pm 5.77$ & $0 \cdot 16 \pm 0 \cdot 02$ & $5 \cdot 58 \pm 0 \cdot 17$ & $0.57 \pm 0.09$ & $0 \cdot 61 \pm 0.07$ \\
\hline & $11: 00$ & $54 \cdot 27 \pm 1 \cdot 04$ & $0 \cdot 20 \pm 0 \cdot 04$ & $5 \cdot 32 \pm 0 \cdot 29$ & $0.51 \pm 0.08$ & $0 \cdot 28 \pm 0 \cdot 11$ \\
\hline & 12:00 & $58 \cdot 77 \pm 3 \cdot 06$ & $0 \cdot 15 \pm 0 \cdot 02$ & $5 \cdot 13 \pm 0 \cdot 18$ & $0.63 \pm 0.20$ & $0 \cdot 23 \pm 0.06$ \\
\hline & $13: 00$ & $57 \cdot 33 \pm 5 \cdot 85$ & $0 \cdot 17 \pm 0 \cdot 05$ & $5 \cdot 32 \pm 0 \cdot 30$ & $0 \cdot 52 \pm 0 \cdot 11$ & $0 \cdot 29 \pm 0 \cdot 02$ \\
\hline & $14: 00$ & $55 \cdot 98 \pm 2 \cdot 01$ & $0 \cdot 08 \pm 0 \cdot 02$ & $5 \cdot 65 \pm 0.37$ & $0 \cdot 49 \pm 0 \cdot 10$ & $0 \cdot 35 \pm 0.06$ \\
\hline & $15: 00$ & $57 \cdot 94 \pm 0.72$ & $0 \cdot 12 \pm 0 \cdot 04$ & $5 \cdot 75 \pm 0.41$ & $0 \cdot 54 \pm 0 \cdot 11$ & $0 \cdot 24 \pm 0 \cdot 10$ \\
\hline & $16: 00$ & $53 \cdot 31 \pm 0.65$ & $0 \cdot 08 \pm 0.01$ & $5 \cdot 80 \pm 0 \cdot 23$ & $0.74 \pm 0.11$ & $0 \cdot 30 \pm 0 \cdot 11$ \\
\hline & $17: 00$ & $57 \cdot 98 \pm 1 \cdot 19$ & $0.07 \pm 0.02$ & $5.93 \pm 0.39$ & $0.78 \pm 0.17$ & $0 \cdot 70 \pm 0.31$ \\
\hline & $18: 00$ & $61 \cdot 95 \pm 0.07$ & $0.07 \pm 0.02$ & $6.43 \pm 0.42$ & $0 \cdot 70 \pm 0.13$ & $0 \cdot 14 \pm 0 \cdot 05$ \\
\hline & 19:00 & $58 \cdot 53 \pm 4 \cdot 86$ & $0 \cdot 06 \pm 0.01$ & $6.67 \pm 0.56$ & $0.53 \pm 0.08$ & $0 \cdot 23 \pm 0 \cdot 05$ \\
\hline & 20:00 & $57 \cdot 84 \pm 4 \cdot 80$ & $0 \cdot 08 \pm 0 \cdot 01$ & $7 \cdot 47 \pm 0.51$ & $0.84 \pm 0.14$ & $0 \cdot 16 \pm 0.02$ \\
\hline & 21:00 & $58 \cdot 64 \pm 1 \cdot 48$ & $0.07 \pm 0.01$ & $10 \cdot 53 \pm 0 \cdot 81$ & $0.72 \pm 0.09$ & $0 \cdot 08 \pm 0 \cdot 02$ \\
\hline & $22: 00$ & $51 \cdot 85 \pm 6 \cdot 13$ & $0.08 \pm 0.02$ & $9 \cdot 65 \pm 0.46$ & $0 \cdot 70 \pm 0 \cdot 11$ & $0.23 \pm 0.09$ \\
\hline & $23: 00$ & $103 \cdot 97 \pm 39 \cdot 12$ & $0 \cdot 08 \pm 0.01$ & $9 \cdot 15 \pm 0 \cdot 38$ & $0.65 \pm 0.18$ & $0 \cdot 04 \pm 0.01$ \\
\hline & 0:00 & $160 \cdot 18 \pm 56 \cdot 00$ & $0 \cdot 08 \pm 0 \cdot 01$ & $8 \cdot 80 \pm 0.53$ & $0.40 \pm 0.09$ & $0 \cdot 10 \pm 0.07$ \\
\hline & $1: 00$ & $57 \cdot 14 \pm 6 \cdot 48$ & $0 \cdot 08 \pm 0.02$ & $8 \cdot 22 \pm 0.54$ & $0.52 \pm 0.11$ & $0 \cdot 20 \pm 0.07$ \\
\hline & $2: 00$ & $54 \cdot 89 \pm 6 \cdot 46$ & $0 \cdot 08 \pm 0.02$ & $7 \cdot 96 \pm 0.32$ & $0.62 \pm 0.11$ & $0.12 \pm 0.06$ \\
\hline & $3: 00$ & $59 \cdot 48 \pm 2 \cdot 85$ & $0.09 \pm 0.02$ & $7 \cdot 22 \pm 0 \cdot 17$ & $0.65 \pm 0.17$ & $0 \cdot 10 \pm 0 \cdot 07$ \\
\hline & $4: 00$ & $57 \cdot 04 \pm 7 \cdot 54$ & $0 \cdot 14 \pm 0.05$ & $7 \cdot 22 \pm 0 \cdot 22$ & $0 \cdot 48 \pm 0 \cdot 11$ & $0 \cdot 12 \pm 0 \cdot 05$ \\
\hline & $5: 00$ & $56 \cdot 82 \pm 6 \cdot 79$ & $0 \cdot 11 \pm 0 \cdot 02$ & $6 \cdot 73 \pm 0 \cdot 34$ & $0.31 \pm 0.07$ & $0 \cdot 41 \pm 0 \cdot 14$ \\
\hline & Day 26 & & & & & \\
\hline All pigs fed twice daily (feed & $8: 00$ & $143 \cdot 90 \pm 31.99$ & $0 \cdot 38 \pm 0 \cdot 10$ & $5 \cdot 10 \pm 0 \cdot 45$ & $0 \cdot 01 \pm 0 \cdot 00$ & $1 \cdot 04 \pm 0 \cdot 34$ \\
\hline in trays for $1 \mathrm{~h} \times 2$ ) & 9:00 & $204 \cdot 47 \pm 23 \cdot 12$ & $0 \cdot 21 \pm 0 \cdot 02$ & $6 \cdot 23 \pm 0.67$ & $0 \cdot 01 \pm 0 \cdot 00$ & $0 \cdot 41 \pm 0 \cdot 13$ \\
\hline & $10: 00$ & $210 \cdot 87 \pm 15 \cdot 62$ & $0 \cdot 17 \pm 0 \cdot 03$ & $5 \cdot 43 \pm 0 \cdot 72$ & $0 \cdot 98 \pm 0 \cdot 19$ & $0 \cdot 26 \pm 0 \cdot 03$ \\
\hline & 11:00 & $184 \cdot 03 \pm 12 \cdot 22$ & $0 \cdot 28 \pm 0 \cdot 03$ & $5 \cdot 17 \pm 0 \cdot 54$ & $0 \cdot 55 \pm 0 \cdot 12$ & $0 \cdot 24 \pm 0 \cdot 02$ \\
\hline & $12: 00$ & $171 \cdot 97 \pm 8 \cdot 73$ & $0 \cdot 25 \pm 0 \cdot 05$ & $5 \cdot 87 \pm 0 \cdot 54$ & $0 \cdot 35 \pm 0 \cdot 14$ & $0 \cdot 68 \pm 0.14$ \\
\hline & 13:00 & $223 \cdot 87 \pm 26 \cdot 83$ & $0 \cdot 18 \pm 0 \cdot 02$ & $5 \cdot 30 \pm 0 \cdot 61$ & $0 \cdot 32 \pm 0 \cdot 13$ & $0 \cdot 22 \pm 0 \cdot 03$ \\
\hline & $14: 00$ & $221 \cdot 10 \pm 6 \cdot 66$ & $0 \cdot 21 \pm 0 \cdot 02$ & $6 \cdot 30 \pm 0 \cdot 58$ & $0 \cdot 16 \pm 0 \cdot 08$ & $0 \cdot 87 \pm 0 \cdot 25$ \\
\hline & $15: 00$ & $163 \cdot 17 \pm 10 \cdot 56$ & $0 \cdot 16 \pm 0 \cdot 01$ & $5 \cdot 03 \pm 0 \cdot 16$ & $0.11 \pm 0.08$ & $0 \cdot 11 \pm 0 \cdot 05$ \\
\hline & $16: 00$ & $184 \cdot 90 \pm 20 \cdot 08$ & $0 \cdot 14 \pm 0 \cdot 01$ & $5 \cdot 15 \pm 0 \cdot 08$ & $0 \cdot 03 \pm 0 \cdot 02$ & $0.06 \pm 0.02$ \\
\hline & $17: 00$ & $182 \cdot 20 \pm 16 \cdot 88$ & $0 \cdot 16 \pm 0.03$ & $5 \cdot 03 \pm 0 \cdot 24$ & $0 \cdot 54 \pm 0 \cdot 18$ & $0 \cdot 54 \pm 0 \cdot 21$ \\
\hline & $18: 00$ & $254 \cdot 40 \pm 12 \cdot 28$ & $0 \cdot 15 \pm 0 \cdot 01$ & $4 \cdot 57 \pm 0 \cdot 21$ & $0 \cdot 16 \pm 0 \cdot 10$ & $0 \cdot 39 \pm 0.03$ \\
\hline & 19:00 & $260 \cdot 30 \pm 30 \cdot 27$ & $0 \cdot 13 \pm 0 \cdot 01$ & $4 \cdot 83 \pm 0 \cdot 17$ & $0 \cdot 20 \pm 0 \cdot 15$ & $0 \cdot 24 \pm 0.09$ \\
\hline & Day 27 & & & & & \\
\hline All pigs fed once (feed in trays & 8:00 & $153 \cdot 17 \pm 18 \cdot 40$ & $0 \cdot 54 \pm 0 \cdot 04$ & $4 \cdot 83 \pm 0 \cdot 24$ & $0 \cdot 09 \pm 0 \cdot 05$ & $0 \cdot 06 \pm 0 \cdot 02$ \\
\hline for $1 \mathrm{~h} \times 1$ ) morning & 9:00 & $211 \cdot 30 \pm 12 \cdot 34$ & $0 \cdot 21 \pm 0 \cdot 04$ & $4 \cdot 67 \pm 0.09$ & $0 \cdot 04 \pm 0 \cdot 03$ & $0 \cdot 10 \pm 0 \cdot 04$ \\
\hline feed $=$ sham feed & $10: 00$ & $225 \cdot 07 \pm 9 \cdot 46$ & $0 \cdot 21 \pm 0 \cdot 03$ & $4 \cdot 60 \pm 0 \cdot 09$ & $0 \cdot 02 \pm 0 \cdot 01$ & $1 \cdot 25 \pm 0 \cdot 24$ \\
\hline & $11: 00$ & $253 \cdot 80 \pm 9 \cdot 60$ & $0 \cdot 25 \pm 0 \cdot 02$ & $4 \cdot 45 \pm 0 \cdot 10$ & $0 \cdot 04 \pm 0 \cdot 03$ & $1 \cdot 01 \pm 0 \cdot 32$ \\
\hline & $12: 00$ & $244 \cdot 50 \pm 20 \cdot 21$ & $0 \cdot 41 \pm 0 \cdot 05$ & $4 \cdot 76 \pm 0 \cdot 31$ & $0 \cdot 01 \pm 0 \cdot 00$ & $0 \cdot 20 \pm 0 \cdot 04$ \\
\hline & $13: 00$ & $258 \cdot 63 \pm 15 \cdot 31$ & $0 \cdot 41 \pm 0 \cdot 04$ & $4 \cdot 51 \pm 0 \cdot 12$ & $0 \cdot 01 \pm 0 \cdot 00$ & $0 \cdot 11 \pm 0 \cdot 05$ \\
\hline & $14: 00$ & $265 \cdot 20 \pm 10 \cdot 88$ & $0 \cdot 56 \pm 0.06$ & $4 \cdot 39 \pm 0 \cdot 14$ & $0 \cdot 01 \pm 0 \cdot 00$ & $0 \cdot 76 \pm 0 \cdot 15$ \\
\hline & $15: 00$ & $260 \cdot 47 \pm 19 \cdot 95$ & $0 \cdot 56 \pm 0 \cdot 05$ & $5 \cdot 01 \pm 0 \cdot 21$ & $0 \cdot 01 \pm 0 \cdot 00$ & $0 \cdot 43 \pm 0.14$ \\
\hline & $16: 00$ & $247 \cdot 87 \pm 18.94$ & $0.68 \pm 0.05$ & $4 \cdot 90 \pm 0 \cdot 20$ & $0.03 \pm 0.02$ & $0 \cdot 20 \pm 0 \cdot 01$ \\
\hline & $17: 00$ & $284 \cdot 43 \pm 21 \cdot 05$ & $0.17 \pm 0.01$ & $7.03 \pm 0.27$ & $0.98 \pm 0.51$ & $0.79 \pm 0.42$ \\
\hline & $18: 00$ & $263.67 \pm 18.99$ & $0 \cdot 18 \pm 0 \cdot 02$ & $5 \cdot 45 \pm 0 \cdot 27$ & $0.91 \pm 0 \cdot 47$ & $0 \cdot 30 \pm 0.16$ \\
\hline & 19:00 & $282 \cdot 90 \pm 8.07$ & $0 \cdot 16 \pm 0 \cdot 02$ & $5 \cdot 90 \pm 0 \cdot 27$ & $0 \cdot 80 \pm 0 \cdot 25$ & $0 \cdot 60 \pm 0 \cdot 17$ \\
\hline
\end{tabular}

Sigma-Aldrich). Non-specific binding was less than 3\%, the assay sensitivity was $0.05 \mathrm{ng} / \mathrm{ml}$ and the inter- and intra-assay coefficients of variation were $9 \cdot 1$ and $13 \cdot 7 \%$ respectively. The $\mathrm{GH}$ antibody was specific for porcine $\mathrm{GH}$ and was supplied by Dr J P McMurtry (Althen \& Gerrits 1976). The standard reference used was obtained from the National Institute of Diabetes and Digestive and Kidney Diseases. The assay sensitivity was $1.0 \mathrm{ng} / \mathrm{ml}$ and the inter- and intra-assay coefficients of variation were $12 \cdot 5$ and $8 \cdot 2 \%$ respectively. Circulating NEFA concentrations were determined by the acyl-CoA synthetase/acyl-CoA oxidase method (NEFA C-test; Wako Chemicals USA, Inc. Richmond, VA, USA). Plasma glucose measurements were determined with a commercially available kit (Glucose Unimate 5 Gluc HK, Roche Products Pty Ltd) using a Roche Cobas Mira automatic analyser. 


\section{Statistical analysis}

Data on feed intake, body weight, hormone and metabolite concentrations were analysed using linear mixed models via the REML procedure using GenStat Release 9 (www.vsni.co.uk). As these were repeated measures data (either hourly over a 24-h period or daily over an 18-day period), adjustments were made for the serial correlation of random errors (using a power model). Significance of fixed effects was assessed using Wald $\chi^{2}$ tests. NEFA, insulin, GH and ghrelin concentrations were analysed on a logarithmic scale. All data are presented as mean \pm s.E.M.

\section{Results}

Live pig performance

Body weights Body weights for all pigs increased over the experimental period. Body weights (mean \pm s.E.M.) for day 1 were $57.50 \pm 2.91 \mathrm{~kg}$, day $1163.49 \pm 2 \cdot 31 \mathrm{~kg}$, day $1970 \cdot 30 \pm 2 \cdot 31 \mathrm{~kg}$ and day $3382 \cdot 63 \pm 2 \cdot 86 \mathrm{~kg}$ (Fig. 1).

\section{Feed intakes}

Ad libitum feeding (regimen $A$ ). Daily feed intake for days 1-6 was $3 \cdot 18 \pm 0 \cdot 06 \mathrm{~kg}$ and did not change $(3 \cdot 17 \pm 0 \cdot 12 \mathrm{~kg})$ on day 7 when pigs were catheterised (Fig. 1).

Twice daily feeding (regimen B). During the first week of entrainment to regimen $\mathrm{B}$, pigs consumed a greater proportion of feed during the afternoon $(1.31 \pm 0.02 \mathrm{~kg})$ when compared with the morning feeding period $(1.09 \pm$ $0.04 \mathrm{~kg})$. After day 7 , intakes for both morning and afternoon periods were similar $(1.39 \pm 0.04 \mathrm{~kg}$ and $1.37 \pm 0.11 \mathrm{~kg}$ respectively). However, feed intakes for this feed regimen were $87 \%$ of ad libitum feeding (regimen A).

Once daily feeding (modified regimen $B$ ). The average feed intake for the $1600-1700 \mathrm{~h}$ feeding period was $1.90 \pm$ $0 \cdot 14 \mathrm{~kg}$, a difference of $60 \%$ when compared with ad libitum feeding (regimen A).

The efficiency of feed utilisation The efficiency of feed utilisation expressed as weight of feed consumed $(\mathrm{kg})$ relative to live weight gain $(\mathrm{kg})$ for the same period is presented in Fig. 1.

Mean (士s.E.M.) feed: gain $(\mathrm{kg} / \mathrm{kg})$ for days $1-11$ was $6 \cdot 26 \pm 2 \cdot 75$, for days $11-19$ was $3 \cdot 23 \pm 0 \cdot 20$ and for days 19-33 was $2 \cdot 78 \pm 0 \cdot 07$.

\section{Hormones and metabolites}

\section{Plasma insulin}

Ad libitum feeding (regimen $A$ ). Apart from a significant $(P=0.03)$ rise in plasma insulin concentration to $0.98 \pm$ $0 \cdot 14 \mathrm{ng} / \mathrm{ml}$ at $0700 \mathrm{~h}$, there was no significant change throughout the remainder of the 24-h sampling period. However, from $1500 \mathrm{~h}$ onwards, the secretory pattern appeared to be cyclical with a periodicity of $6 \mathrm{~h}$ and amplitude of $\sim 0 \cdot 2 \mathrm{ng} / \mathrm{ml}$ (Fig. 2).

Twice daily feeding (regimen B). During the morning and afternoon feed periods (0900-1000 h and 1600-1700 h), circulating insulin concentrations significantly increased $(P<0.001)$ to $0.98 \pm 0.19 \mathrm{ng} / \mathrm{ml}$ and $0.54 \pm 0.18 \mathrm{ng} / \mathrm{ml}$ respectively.

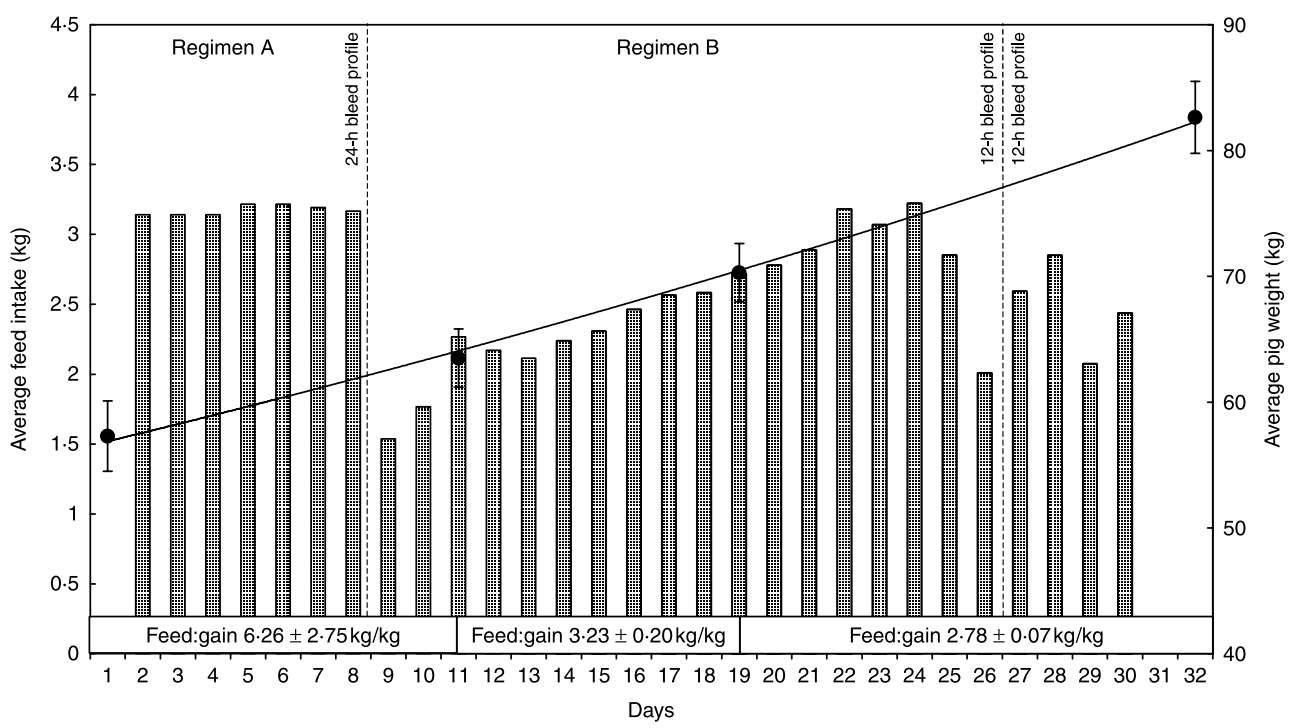

Figure 1 Comparison of mean daily feed intakes, $n=10$ (国), and mean body weights; $n=10(\mathbf{O})$, of pigs recorded during the course of the trial. These were then used to calculate the feed: gain ratio $(\mathrm{kg} / \mathrm{kg})$ for days $1-11,11-19$ and $19-33$. 


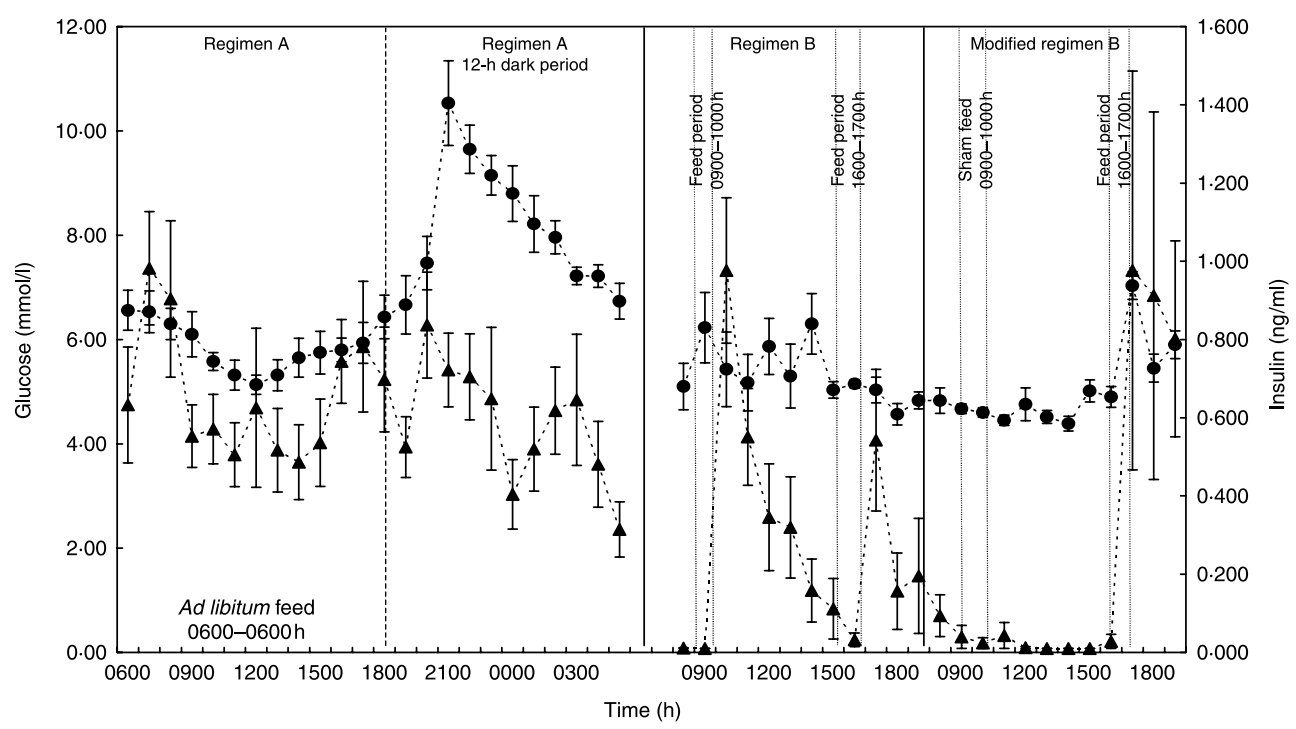

Figure 2 Comparison of circulating plasma glucose, $\mathrm{n}=7(\boldsymbol{\bullet})$, and insulin, $n=7(\boldsymbol{\Delta})$, taken hourly on days 8 , 26 and 27.

Once daily feeding (modified regimen B). From 0900 until $1600 \mathrm{~h}$, plasma insulin concentrations remained constant $(0.02 \pm 0.01 \mathrm{ng} / \mathrm{ml})$ and were significantly $(P=0.02)$ lower when compared with concentrations for the same period during the previous day $(0.33 \pm 0.04 \mathrm{ng} / \mathrm{ml})$. Following re-feeding at $1600 \mathrm{~h}$, insulin concentrations increased significantly $(P<0.001)$ to $0.98 \pm 0.51 \mathrm{ng} / \mathrm{ml}$ and were elevated for a further $2 \mathrm{~h}$ after feed was removed at $1700 \mathrm{~h}$.

\section{Plasma glucose}

Ad libitum feeding (regimen $A$ ). The photoperiod regimen (12 h light:12 $\mathrm{h}$ darkness cycle) that the pigs were exposed to had a profound effect on the plasma glucose profile. During the light period, plasma glucose decreased from $6.56 \pm 0.38 \mathrm{mmol} / 1$ at $0600 \mathrm{~h}$ to $5 \cdot 13 \pm 0 \cdot 18 \mathrm{mmol} / 1$ by $1200 \mathrm{~h}$ then gradually increased over the afternoon period to $6 \cdot 43 \pm 0.18 \mathrm{mmol} / \mathrm{l}$ by $1800 \mathrm{~h}$. During the dark period, plasma glucose concentrations increased significantly $(P<0 \cdot 001)$ to $10.53 \pm 0.81 \mathrm{mmol} / 1$ at $2100 \mathrm{~h}$ then declined to $6 \cdot 73 \pm 0.34 \mathrm{mmol} / \mathrm{l}$ by $0500 \mathrm{~h}$ (Fig. 2).

Twice daily feeding (regimen B). Plasma glucose concentrations were relatively constant throughout the sampling period with a mean value of $5 \cdot 37 \pm 0 \cdot 14 \mathrm{mmol} / \mathrm{l}$, although concentrations tended to be higher and more variable between 0800 to $1400 \mathrm{~h}(5 \cdot 63 \pm 0 \cdot 23 \mathrm{mmol} / \mathrm{l})$ compared with the remainder of the sampling period $(4 \cdot 97 \pm 0.08 \mathrm{mmol} / \mathrm{l})$.

Once daily feeding (modified regimen B). The plasma glucose profile was relatively constant $(4 \cdot 68 \pm 0 \cdot 06 \mathrm{mmol} / \mathrm{l})$ prior to the onset of re-feeding at $1600 \mathrm{~h}$. Following re-feeding, plasma glucose increased to $5 \cdot 03 \pm 0.24 \mathrm{mmol} / 1$ and remained elevated for a further $2 \mathrm{~h}$ after feed was removed at $1700 \mathrm{~h}$.

\section{Plasma ghrelin}

Ad libitum feeding (regimen $A$ ). Plasma ghrelin concentrations remained relatively constant over the $24-\mathrm{h}$ sampling period $(67 \cdot 2 \pm 5 \cdot 5 \mathrm{pg} / \mathrm{ml}$; Figs 3 and 4$)$.

Twice daily feeding (regimen B). Circulating ghrelin concentrations were variable throughout the 12-h sampling period $(200 \cdot 4 \pm 10 \cdot 2 \mathrm{pg} / \mathrm{ml})$ and values were significantly higher $(P<0.05)$ when compared with the same 12-h sampling period as the ad libitum feeding regimen $(56 \cdot 6 \pm 1 \cdot 0 \mathrm{pg} / \mathrm{ml})$. Three distinct peaks in plasma ghrelin concentrations were observed at $0900 \mathrm{~h}(204 \cdot 5 \pm 23 \cdot 1 \mathrm{pg} / \mathrm{ml}), 1300 \mathrm{~h}(223 \cdot 9 \pm$ $26 \cdot 8 \mathrm{pg} / \mathrm{ml})$ and $1800 \mathrm{~h}(254 \cdot 4 \pm 12 \cdot 3 \mathrm{pg} / \mathrm{ml})$ with corresponding troughs at $1200 \mathrm{~h}(172 \cdot 0 \pm 8 \cdot 7 \mathrm{pg} / \mathrm{ml})$ and $1500 \mathrm{~h}$ $(163.2 \pm 10.6 \mathrm{pg} / \mathrm{ml})$. These peaks and troughs did not appear to be associated with the time of feeding (09001000 and 1600-1700 h).

Once daily feeding (modified regimen B). Mean plasma ghrelin concentrations during the once daily feeding regimen $(245 \cdot 9 \pm 10 \cdot 4 \mathrm{pg} / \mathrm{ml})$ tended to be higher than during the twice daily feeding regimen $(200 \cdot 4 \pm 10 \cdot 2 \mathrm{pg} / \mathrm{ml})$.

\section{Plasma NEFA}

Ad libitum feeding (regimen $A$ ). Plasma NEFA showed little variation throughout the sampling period with average NEFA concentrations of $0 \cdot 10 \pm 0 \cdot 01 \mathrm{mEq} / \mathrm{l}$. These increased significantly $(P<0 \cdot 001)$ to $0 \cdot 20 \pm 0.04 \mathrm{mEq} / 1$ by $1100 \mathrm{~h}$, returning to baseline values $3 \mathrm{~h}$ later, where they remained for the rest of the sampling period (Fig. 3).

Twice daily feeding (regimen B). Mean plasma NEFA concentrations during the twice daily feeding regimen 


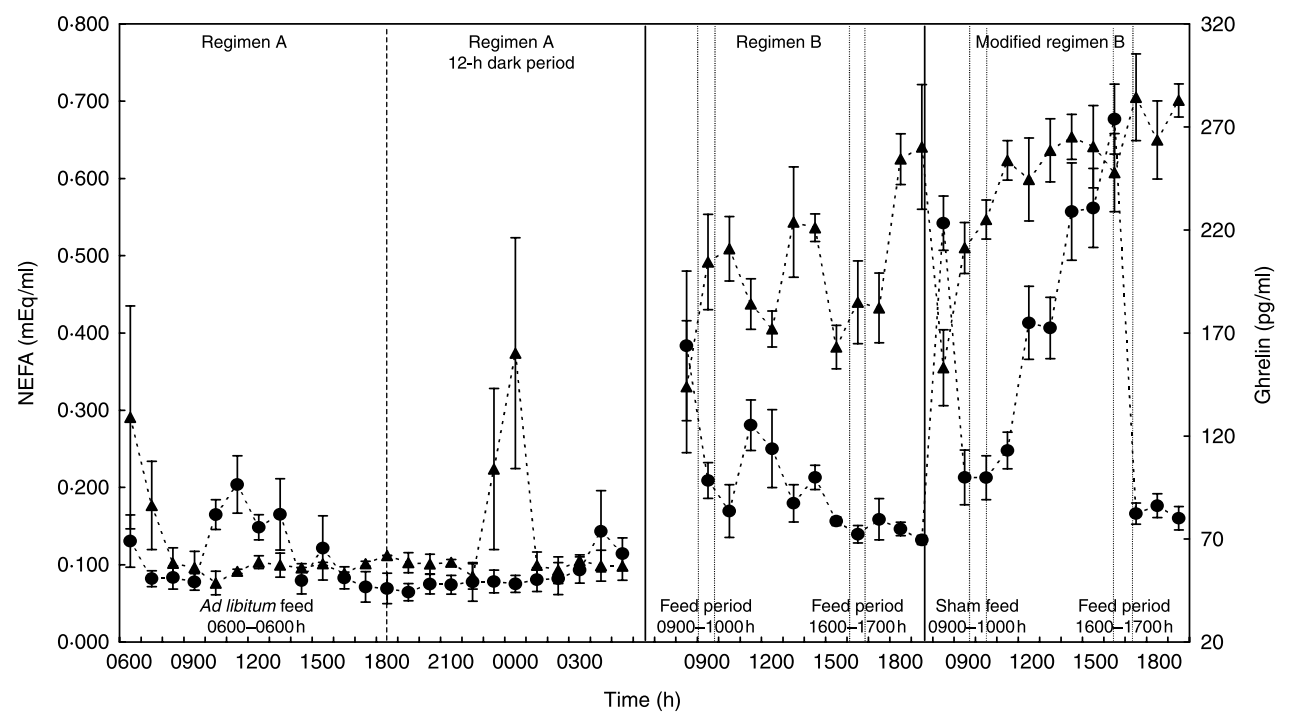

Figure 3 Comparison of circulating plasma NEFA, $n=7(\mathbf{O})$, and ghrelin, $n=7(\boldsymbol{\Lambda})$, taken hourly on days 8 , 26 and 27.

$(0 \cdot 20 \pm 0 \cdot 02 \mathrm{mEq} / \mathrm{l})$ were significantly greater $(P<0 \cdot 05)$ and more variable than when the pigs were fed ad libitum $(0 \cdot 10 \pm$ $0 \cdot 01 \mathrm{mEq} / \mathrm{l})$. Prior to feeding at $0800 \mathrm{~h}$, NEFA concentrations were elevated $(0.38 \pm 0.09 \mathrm{mEq} / \mathrm{l})$. During the feeding period $(0900-1000 \mathrm{~h})$, concentrations declined to $0.17 \pm 0.03 \mathrm{mEq} / 1$ and remained relatively constant $(0 \cdot 20 \pm 0 \cdot 02 \mathrm{mEq} / \mathrm{l})$ throughout the sampling period.

Once daily feeding (modified regimen B). Mean plasma NEFA concentrations for pigs fed once daily $(0 \cdot 36 \pm 0.05 \mathrm{mEq} / \mathrm{l})$ were significantly greater $(P<0 \cdot 05)$ and more variable when compared with pigs fed ad libitum $(0 \cdot 10 \pm 0 \cdot 01 \mathrm{mEq} / \mathrm{l})$ and twice daily $(0 \cdot 20 \pm 0 \cdot 02 \mathrm{mEq} / \mathrm{l})$. From 0800 to $1100 \mathrm{~h}$, pigs displayed a similar pattern in circulating NEFA concentrations to the twice daily feeding regimen. By $1200 \mathrm{~h}$, NEFA concentrations were elevated significantly $(0.41 \pm 0.05 \mathrm{mEq} / \mathrm{l} ; P=0.011)$ and continued to increase to $0.68 \pm 0.05 \mathrm{mEq} / \mathrm{l}$ until pigs were fed at $1600 \mathrm{~h}$ at which time they declined to $0 \cdot 17 \pm 0 \cdot 01 \mathrm{mEq} / 1$ within the hour in which feed was offered.

\section{Plasma GH}

Ad libitum feeding (regimen A). Plasma GH concentrations were released in a pulsatile pattern over the 24-h sampling

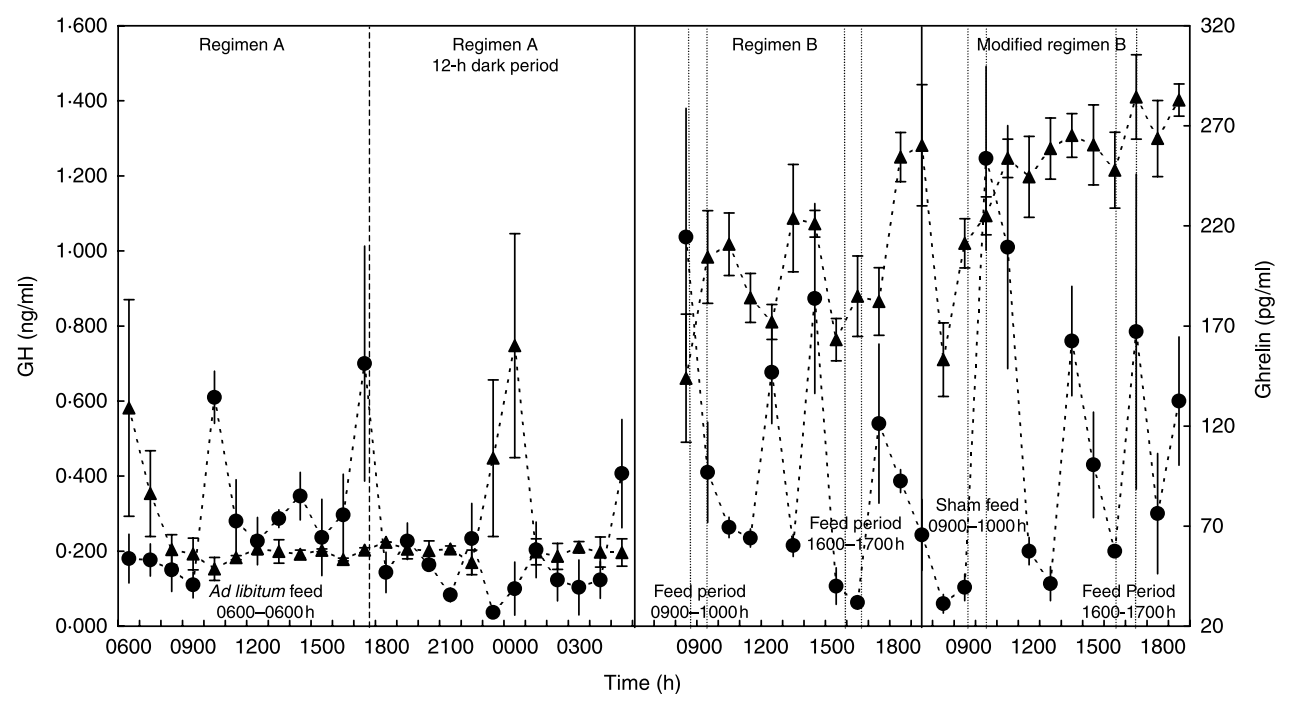

Figure 4 Comparison of circulating plasma $\mathrm{GH}, n=7(\bullet)$, and ghrelin, $n=7(\mathbf{\Delta})$, taken hourly on days 8,26 and 27 . 
period with peaks occurring at $1000 \mathrm{~h},(0 \cdot 61 \pm 0 \cdot 07 \mathrm{ng} / \mathrm{ml})$, $1700 \mathrm{~h}(0 \cdot 70 \pm 0 \cdot 30 \mathrm{ng} / \mathrm{ml})$ and $0500 \mathrm{~h}(0 \cdot 41 \pm 0 \cdot 11 \mathrm{ng} / \mathrm{ml}$ Fig. 4).

Twice daily feeding (regimen B). Circulating GH concentrations displayed a similar pattern of secretion over the $12-\mathrm{h}$ sampling period as for ad libitum feeding. However, the $\mathrm{GH}$ secretory profile was more variable with peaks occurring at $0800 \mathrm{~h}(1.04 \pm 0.34 \mathrm{ng} / \mathrm{ml}), 1200 \mathrm{~h}(0.68 \pm 0.14 \mathrm{ng} / \mathrm{ml})$, $1400 \mathrm{~h}(0 \cdot 87 \pm 0 \cdot 25 \mathrm{ng} / \mathrm{ml})$ and $1700 \mathrm{~h}(0 \cdot 54 \pm 0 \cdot 21 \mathrm{ng} / \mathrm{ml})$.

Once daily feeding (modified regimen B). The plasma GH secretory profile was similar to twice daily feeding although the timing for these peaks were $\sim 2$ h later with $\mathrm{GH}$ peaks occurring at $1000 \mathrm{~h}(1 \cdot 25 \pm 0 \cdot 24 \mathrm{ng} / \mathrm{ml}), 1400 \mathrm{~h}(0 \cdot 76 \pm 0 \cdot 15 \mathrm{ng} / \mathrm{ml})$, $1700 \mathrm{~h}(0 \cdot 79 \pm 0 \cdot 42 \mathrm{ng} / \mathrm{ml})$ and $1900 \mathrm{~h}(0 \cdot 60 \pm 0 \cdot 17 \mathrm{ng} / \mathrm{ml})$.

\section{Behavioural observations}

Observations of pig behaviour are presented in Fig. 5.

Ad libitum feeding (regimen A) Pigs were observed to be more active during the light period (0600-1800 h) and remained recumbent during the dark period (1800-0600 h). This pattern was not affected by the hourly presence of humans to collect blood samples throughout the 24-h period.

Twice daily feeding (regimen B) The activity of the pig increased prior to the onset of the morning feeding period (0900-1000 h) during which feed was consumed constantly for $45 \mathrm{~min}$ until the pigs were satiated and their activity declined until the feed was removed. Between the morning and afternoon feeding periods, pigs were mainly inactive with activity slightly increasing prior to the onset of the afternoon feeding period. Pigs consumed feed constantly for the hour then reclined again to a state of relative inactivity soon after feed was withdrawn.

Once daily feeding (modified regimen $B$ ) The pigs spent more time standing during the $12-\mathrm{h}$ bleed period compared with the twice daily feeding regimen.

\section{Discussion}

The main findings from this study were twofold. The first finding was that plasma ghrelin concentrations were not aligned with either feeding activity or to plasma glucose. The observation that ghrelin status was not related to any metabolic factor in animals fed ad libitum suggests that the secretion of this hormone is not associated with acute feeding responses. We observed periodic feeding activity mainly within the daylight hours and yet ghrelin status remained unaltered over the duration of the 24-h sampling period.

The second finding was the dissociation between plasma glucose and insulin concentrations at night when pigs were offered voluntary access to feed. Even though pigs were observed not to be feeding plasma glucose rose during the darkness-light cycle with little change in plasma insulin concentration. By contrast, plasma glucose and insulin rose in association with feeding activity when pigs were either fed once or twice daily.

The results from the current study suggest that ghrelin expression differs in pigs when compared with other species,

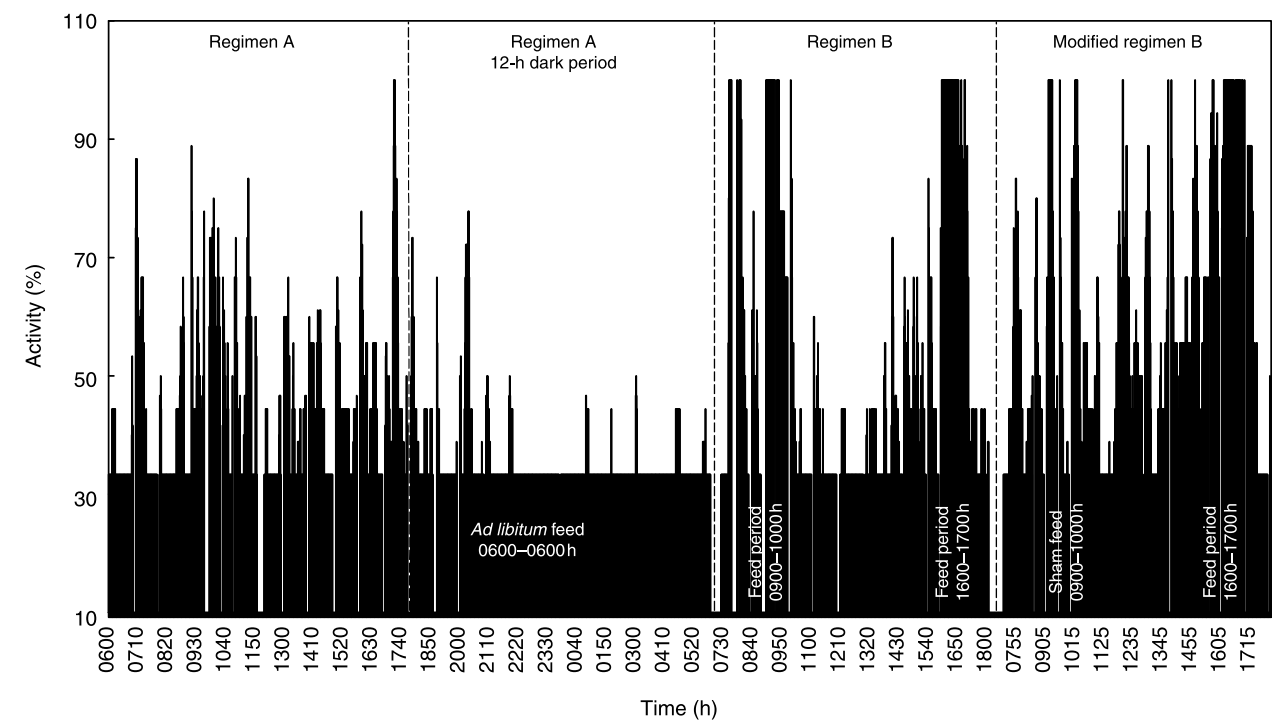

Figure 5 Using video footage, observations of individual pigs lying, sitting and standing were recorded every $30 \mathrm{~s}$ for days 8,26 and 27 . The shaded areas of the graph represent the mean pig activity, $n=6$, as a percentage. If all pigs were lying mean activity would equal $33 \%$ and if all pigs were standing mean activity would equal $100 \%$. 
as no significant preprandial surge or postprandial fall in plasma ghrelin concentrations were shown regardless of the feeding regimen imposed. Studies in humans placed on a fixed feeding regimen of three meals per day show a preprandial rise in plasma ghrelin followed by a postprandial fall at each accompanying meal (Cummings et al. 2001). In the current study, there was no alignment between ghrelin secretory pattern and the time of feeding for the twice daily feeding regimen. Similarly, the studies of Sugino et al. (2002) have also shown a preprandial rise in ghrelin in Suffolk rams maintained on a once daily feeding regimen. However, these studies have shown that there were no plasma ghrelin surges in animals fed ad libitum, a finding consistent with the present study. A proposed function for the preprandial rise in ghrelin is to stimulate hunger and initiate feeding (Cummings $e t$ al. 2001), although it now appears that this rise may simply be an anticipatory response to a conditioned physiological reflex rather than a feeding signal per se (Sugino et al. 2002). This notion is supported by the recent findings of Drazen et al. (2006) who have demonstrated with rats, that the secretion of ghrelin pre- and postprandially can be entrained by feeding meals at a set time and duration independent of the dietary energy status of the animal. Our study did not show a significant preprandial ghrelin surge or postprandial fall when pigs were fed either ad libitum nor when entrained to a periodic feeding regimen. This finding may be a consequence of using growing pigs, as pre-pubertal children are less sensitive to the inhibitory influence of food intake on ghrelin secretion when compared with adults (Bellone et al. 2004). It may also be the result of less frequent sampling or simply reflect a species difference. Alternatively, as suggested by Sugino et al. (2002), the lack of a ghrelin surge and decline may be attributed to the positive energy balance in which these animals were maintained. However, our behavioural data suggest that the pigs in the current study were not fed to reach satiety, as their increased activity prior to feeding resembled a heightened awareness for feed. This observation is corroborated by our endocrine data, which show metabolite and metabolic hormone patterns consistent with those for fasted gilts (Govoni et al. 2005). This was not the case when animals were offered the feed ad libitum. Our data suggest that pigs fed ad libitum consume feed at regular intervals and mainly throughout the daylight hours when housed in individual pens. However, it should also be noted that the ghrelin RIA used in the current study measured total ghrelin concentrations and that this may not reflect the biologically active form, acylated ghrelin (Paik et al. 2006). Therefore, any future studies should also measure acylated ghrelin and this may contribute to a better understanding of the pattern and control of ghrelin secretion in pigs.

The dissociation between feeding frequency, circulating glucose and insulin status in animals fed ad libitum is less easily explained. It may be related to fluctuations in insulin sensitivity during the period of darkness, which is also under the influence of suprachiasmatic nucleus $(\mathrm{SCN})(\mathrm{La}$ Fleur 2003). La Fleur (2003) has postulated that glucose metabolism is regulated in a rhythmic fashion over a 24-h light/darkness cycle through the endogenous circadian oscillator located within the SCN and that this rhythm is independent of feeding activity. Studies in humans and rodents have shown an alteration in both plasma glucose and insulin concentrations and variation in sensitivity of tissues to insulin over a 24-h light/darkness period. For example, humans have a higher glucose output and insulin requirement in the early morning hours (Carroll \& Nestel 1973, Lee et al. 1992), whereas rodents have higher concentrations of glucose and insulin in the dark period compared with the light period (Pauly \& Scheving 1967), which may be associated with the initiation of physical activity (La Fleur 2003): it is important to recognise that rodents are nocturnally active and circulating insulin and glucose concentrations are higher during the dark phase (Pauly \& Scheving 1967). Similarly, diurnal fluctuations in the actions of the $\mathrm{D}_{2}$ dopamine receptor agonist bromocryptine on insulin sensitivity have been observed, with increased sensitivity in the morning and suppression in hepatic glucose production in the afternoon (Luo et al. 1999). Therefore, during an ad libitum feeding regimen, insulin secretion over the 24-h light/darkness cycle may be aligned more to whole body energy balance of the pig rather than to feeding behaviour or circulating glucose concentrations.

By contrast, when pigs were entrained to feed twice daily, we observed the classical insulin response to the consumption of food and the subsequent release of glucose. It is of interest that the insulin response to the $0900-1000 \mathrm{~h}$ feeding period was greater than that for the $1600-1700 \mathrm{~h}$ feeding period, even though similar quantities of feed were consumed for these two periods. Comparable findings have also been described for pigs entrained to feed twice daily at 12-h intervals where the postprandial insulin concentration was $75 \%$ greater for the morning compared with the evening feeding periods (Koopmans et al. 2005). Increased morning concentrations of both glucose and insulin have also been observed in humans (Bolli \& Gerich 1984, Trumper et al. 1995), which has been suggested as an anticipatory response of glucose metabolism to the upcoming period of activity (La Fleur 2003). Therefore, the differences in plasma insulin secretion between the two feeding periods may be the result of a difference in the activity of the pig at these times. Our behavioural data suggest that these pigs tended to be more active during the morning hours than in the afternoon and that this difference in activity may induce changes in both plasma insulin concentrations and/or insulin tissue sensitivity under the influence of the SCN (La Fleur 2003).

Studies in a number of different species have attempted to identify a metabolic signal that regulates ghrelin secretion. These studies have produced conflicting results, which have complicated our understanding of the metabolic role for ghrelin. For example, studies in humans (Flanagan et al. 2003, Broglio et al. 2004) and rodents (Ishii et al. 2002) have demonstrated either a negative relationship between insulin and ghrelin or no significant relationship (Caixas et al. 2002, Espelund et al. 2005). Although in the same study, Espelund 
et al. (2005) observed a circadian rhythm in plasma ghrelin, which had a strong negative correlation with plasma cortisol concentrations but was unrelated to GH status. Even from the same species, differences have been reported: Kamegai et al. (2004) demonstrated that insulin and leptin inhibited ghrelin while glucagon stimulated ghrelin secretion from an isolated perfused rat stomach, in a dose-dependent manner, while the expression of the ghrelin gene in the stomach either increased (Toshinai et al. 2001) or was unaffected (Lee et al. 2002) following the insulin or leptin treatment in rats in vivo.

Results from the current study suggest that ghrelin secretion is not modulated by changes in either insulin or glucose secretion irrespective of the feeding regimen. This result is in contrast to that of Govoni et al. (2005) who have shown in gilts a decline in insulin secretion with a corresponding rise in ghrelin levels. The discrepancy between these two studies may be a consequence of the experimental design and in particular the severity of the fasting: Govoni et al. (2005) fasted gilts for $72 \mathrm{~h}$ then re-fed these same animals, whereas in the current study pigs were allowed to adapt to the new feeding regimen by being habituated to a twice daily feeding pattern over a period of 2 weeks prior to the onset of the sampling. The altered endocrine status of pigs subjected to the fasting period in the Govoni et al. (2005) study are similar to the metabolic responses observed for the once daily feeding pattern in the present study with reduced insulin and elevated NEFA concentrations accompanied by increasing ghrelin and GH levels. The elevated NEFA concentrations are indicative of negative energy balance and are usually associated with protracted periods of inappetance or feed withdrawal, as we have reported previously in fallow deer (Newman et al. 1998).

Results from our current study indicate that insulin may not play an important role in ghrelin secretion, as the secretory profiles for these hormones were not related irrespective of the feeding regimen. Sugino et al. (2002) demonstrated similar findings by showing a negative relationship between plasma ghrelin and the feeding regimen. In their study, ghrelin concentrations increased as the period of feeding decreased; sheep fed twice daily had a significantly higher calculated area under the response curve for plasma ghrelin when compared with animals fed four times daily, which in turn was significantly higher when compared with animals fed ad libitum. Similarly, in the current study, there was a negative association between plasma ghrelin concentrations and the corresponding feeding regimen; plasma ghrelin concentrations were reduced with ad libitum feeding and elevated in response to once daily feeding. Interestingly, the plasma ghrelin secretory profile also showed distinct differences in response to the three feeding regimens. The ghrelin profile for the twice daily feed pattern showed three distinct peaks over the 12-h period occurring at 1000, 1400 and $1900 \mathrm{~h}$, a pattern not dissimilar to that observed for humans (Cummings et al. 2001). Whereas when pigs were fed once daily, the plasma ghrelin profile showed no distinct peaks with concentrations rising over the 12 -h sampling period. These data suggest that both circulating ghrelin

www.endocrinology-journals.org concentrations and its secretory profile are responsive to the amount of feed an animal consumes. Therefore, the type of feeding regimen an animal is exposed to, irrespective of species, may influence ghrelin secretion, which in turn reflects the energy status of the animal.

In the current study, the increase in the variability of the secretion of plasma GH coincided with the elevation in plasma ghrelin concentrations in pigs fed once or twice daily. This finding is in keeping with other studies that show the stimulatory nature of ghrelin on $\mathrm{GH}$ secretion and has been described for a variety of species including the pig (Kojima et al. 1999, Arvat et al. 2000, Sugino et al. 2002, Hashizume et al. 2003). It has been suggested that ghrelin has a modulatory role on $\mathrm{GH}$ secretion rather than a direct effect on the physiological system that stimulates the endogenous production and secretion of the $\mathrm{GH}$ pulse (Broglio et al. 2003, Cummings \& Shannon 2003). However, our data suggest that ghrelin may influence the pulsatility of $\mathrm{GH}$ secretion in the pig as the number of $\mathrm{GH}$ pulses increased from two over a 12-h period $(0800-2000 \mathrm{~h})$ in ad libitum fed pigs to four for both once and twice daily feeding. This difference may simply reflect a species difference as $\mathrm{GH}$ plays an important role in the pig for both weight gain and lipid metabolism (Etherton et al. 1986) and as such the differences in the patterns of variations of both plasma ghrelin and $\mathrm{GH}$ concentrations may signify this difference.

It is conceivable that the increase in the pulsatility of $\mathrm{GH}$ secretion in the current study may act to stimulate lipid mobilisation, as NEFA levels were elevated when pigs were fed twice daily and were further elevated when fed once a day compared with those fed ad libitum. A relationship between plasma NEFA and ghrelin concentrations in response to a 54-h fast has been reported in grower pigs (Inoue et al. 2005) and also in fasted gilts (Govoni et al. 2005). Our results also show an association between plasma ghrelin and NEFA concentrations in pigs that were fed once daily, a difference in feed consumption of $60 \%$ when compared with ad libitum feeding. Therefore, the plasma ghrelin concentrations may simply reflect the long-term energy status of the pig rather than acting as an acute regulator of energy intake: in effect it acts as a negative feedback signal to the satiety centre of the hypothalamus (Kojima et al. 1999) to maintain live weight.

Although this study has not been able to clearly identify a physiological role for circulating ghrelin concentrations in the pig, we have shown that porcine ghrelin expression does differ to that in other mammals. There is neither a preprandial rise nor postprandial fall in circulating ghrelin concentrations in response to feeding. Plasma ghrelin does not appear to influence feeding behaviour acutely; however, it does reflect the energy status of the pig.

Our study has also demonstrated that insulin sensitivity is more closely aligned to a twice daily feeding pattern than to an ad libitum feeding regimen. In view of its importance in promoting growth processes, it is tempting to speculate that interval feeding may lead to more efficient utilisation of energy substrate for metabolism and growth in grower pigs: this was certainly the case in the present study with an 
improvement in the efficiency in feed utilisation between the ad libitum and twice daily feeding periods. The practicalities of implementing such a feeding regimen and the improvements in feed utilisation achieved for growth on a commercial scale remain to be investigated in further studies.

\section{Declaration of Interest}

The authors declare that there is no conflict of interest that would prejudice the impartiality of this scientific work.

\section{Funding}

The authors are grateful to Pfizer Animal Health and to the Australian Research Council for financial support.

\section{Acknowledgements}

The authors would also like to extend their appreciation to Dr Jeff Downing for invaluable discussions and to Mr Donald Nicholson for his expert technical assistance.

\section{References}

Althen TG \& Gerrits RJ 1976 Metabolic clearance and secretion rates of porcine growth hormone in genetically lean and obese swine. Endocrinology 99 511-515.

Anderson DM \& Elsley FWH 1969 A note on the use of indwelling catheters in conscious adult pigs. Journal of Agricultural Science 72 475-477.

Ariyasu H, Takaya K, Tagami T, Ogawa Y, Hosoda K, Akamizu T, Suda M, Koh T, Natsui K, Toyooka S et al. 2001 Stomach is a major source of circulating ghrelin, and feeding state determines plasma ghrelin-like immunoreactivity levels in humans. Journal of Clinical Endocrinology and Metabolism 86 4753-4758.

Arvat E, Vito L, Broglio F, Papotti M, Muccioli G, Dieguez C, Casanueva FF, Deghenghi R, Camanni F \& Ghigo E 2000 Preliminary evidence that Ghrelin, the natural GH secretagogue (GHS) - receptor ligand, strongly stimulates GH secretion in humans. Journal of Endocrinological Investigation $\mathbf{2 3}$ 493-495.

Bellone S, Castellino N, Broglio F, Rapa A, Vivenza D, Radetti G, Bellone J, Gottero C, Ghigo E \& Bona G 2004 Ghrelin secretion in childhood is refractory to the inhibitory effect of feeding. Journal of Clinical Endocrinology and Metabolism 89 1662-1665.

Bolli GB \& Gerich JE 1984 The ‘dawn phenomenon' - a common occurance in both non-insulin-dependent and insulin-dependent diabetes mellitus. New England Journal of Medicine 310 746-750.

Broglio F, Benso A, Castiglioni C, Gottero C, Prodam F, Destefanis S, Gauna C, van der Lely AJ, Deghenghi R, Bo M et al. 2003 The endocrine response to ghrelin as a function of gender in humans in young and elderly subjects. Journal of Clinical Endocrinology and Metabolism 88 1537-1542.

Broglio F, Gottero C, Prodam F, Destefanis S, Gauna C, Me E, Riganti F, Vivenza D, Rapa A, Martina V et al. 2004 Ghrelin secretion is inhibited by glucose load and insulin-induced hypoglycaemia but unaffected by glucogon and arginine in humans. Clinical Endocrinology 61 503-509.

Caixas A, Bashore C, Nash W, Pi-Sunyer F \& Laferrère B 2002 Insulin unlike food intake, does not suppress ghrelin in human subjects. Journal of Clinical Endocrinology and Metabolism 87 1902-1906.

Carroll KF \& Nestel PJ 1973 Diurnal variation in glucose tolerance and insulin secretion in man. Diabetes 22 333-348.

Cummings DE \& Shannon MH 2003 Roles for ghrelin in the regulation of appetite and body weight. Archives of Surgery 138 389-396.
Cummings DE, Purnell JQ, Frayo RS, Schmidova K, Wisse BE \& Weigle DS 2001 A preprandial rise in plasma ghrelin levels suggests a role in meal initiation in humans. Diabetes 50 1714-1719.

Date Y, Kojima M, Hosoda H, Sawaguchi A, Mondal MS, Saganuma T, Matsukura S, Kangawa K \& Nakazata M 2000 Ghrelin a novel growth hormone-releasing acylated peptide, is synthesized in a distinct endocrine cell type in the gastrointestinal tracts of rats and humans. Endocrinology 141 4225-4261.

Dornonville de la Cour C, Björkqvist M, Sandvik AK, Bakke I, Zhao CM, Chen D \& Håkanson R 2001 A-like cells in the rat stomach contain ghrelin and do not operate under gastrin control. Regulatory Peptides 99 141-150.

Downing JA, Joss J, Connell P \& Scaramuzzi RJ 1995 Ovulation rate and the concentrations of gonadotrophic and metabolic hormones in ewes fed lupin grain. Journal of Reproduction and Fertility 103 137-145.

Drazen DL, Vahl TP, D’Alessio DA, Seeley RJ \& Woods SC 2006 Effects of a fixed meal pattern on ghrelin secretion: evidence for a learned response independent of nutritional status. Endocrinology 147 23-30.

Erdmann J, Lippl F \& Schusdziarra V 2003 Differential effect of protein and fat on plasma ghrelin levels in man. Regulatory Peptides 116 101-107.

Espelund U, Krarup TK, Højlund K, Beck-Nielsen H, Clausen JT, Hansen BS, Ørskov H, Jørgensen JOL \& Frystyk J 2005 Fasting unmasks a strong inverse association between ghrelin and cortisol in serum: studies in obese and normal-weight subjects. Journal of Clinical Endocrinology and Metabolism 90 741-746.

Etherton TD, Wiggins JP, Chung CS, Evock CM, Rebhun JF \& Walton PE 1986 Stimulation of pig growth performance by porcine growth hormone and growth hormone-releasing factor. Journal of Animal Science 63 1389-1399.

Flanagan DE, Evans ML, Monsod TP, Rife F, Heptulla RA, Tamborlane WV \& Sherwin RS 2003 The influence of insulin on circulating ghrelin. American Journal of Physiology Endocrinology and Metabolism 284 E313-E316.

Gomez G, Englander EW \& Greeley GH Jr 2004 Nutrient inhibition of ghrelin secretion in the fasted rat. Regulatory Peptides 117 33-36.

Govoni N, Iasio RD, Cocco C, Parmeggiani A, Galeati G, Pagotto U, Brancia C, Spinaci M, Tamanini C, Pasquali R et al. 2005 Gastric immunolocalisation and plasma profiles of acyl-ghrelin inn fasted and fasted-refed prepuberal gilts. Journal of Endocrinology 186 505-513.

Hashizume T, Horiuchi M, Tate N, Nonka S, Mikami U \& Kojima M 2003 Effects of ghrelin on growth hormone secretion from cultured adenohypophysial cells in pigs. Domestic Animal Endocrinology 24 209-218.

Hayashida T, Murakami K, Mogi K, Nishihara M, Nakazato M, Mondal MS, Horii Y, Kojima M, Kangawa K \& Murakami N 2001 Ghrelin in domestic animals: distribution in stomach and its possible role. Domestic Animal Endocrinology 21 17-24.

Horvath TL, Diano S, Sotonyi P, Heiman M \& Tschöp M 2001 Minireview: ghrelin and the regulation of energy balance. A hypothalamic perspective. Endocrinology 142 4163-4169.

Inoue H, Watanuki M, Myint HT, Ito T, Kuwayama H \& Hidari H 2005 Effects of fasting and refeeding on plasma concentrations of leptin, ghrelin, insulin, growth hormone and metabolites in swine. Animal Science Journal 76 367-374.

Ishii S, Kamegai J, Tamura H, Shimizu T, Sugihara H \& Oikawa S 2002 Role of ghrelin in streptozotocin-induced diabetic hyperphagia. Endocrinology 143 4934-4937.

Kamegai J, Tamura H, Shimizu T, Ishii S, Sugihara H \& Wakabayashi I 2000 Central effect of ghrelin, an endogenous growth hormone secretagogue, on hypothalamic peptide gene expression. Endocrinology 141 4797-4800.

Kamegai J, Tamura H, Shimizu T, Ishii S, Sugihara H \& Oikawa S 2004 Effects of insulin, leptin, and glucagon on ghrelin secretion from isolated perfused rat stomach. Regulatory Peptides 119 77-81.

Kojima M, Hosoda M, Date Y, Nakazato M, Matsuo H \& Kangawa K 1999 Ghrelin is a growth-hormone-releasing acylated peptide from stomach. Nature 402 656-660.

Koopmans SJ, van der Meulen J, Dekker R, Corbijin H \& Mroz Z 2005 Diurnal rhythms in plasma cortisol, insulin, glucose, lactate and urea in pigs fed identical meals at 12-hourly intervals. Physiology and Behavior 84 497-503.

La Fleur SE 2003 Daily rhythms in glucose metabolism: suprachiasmatic nucleus output to peripheral tissue. Journal of Endocrinology 15 315-322. 
Lee A, Ader M, Bray GA \& Bergman RN 1992 Diurnal variation in glucose tolerance. Cyclic suppression of insulin action and insulin secretion in normal-weight, but not obese, subjects. Diabetes 41 742-749.

Lee H-M, Wang G, Englander EW, Kojima M \& Greeley GH Jr 2002 Ghrelin, a new gastrointestinal endocrine peptide that stimulates insulin secretion: enteric distribution, ontogeny, influence of endocrine, and dietary manipulations. Endocrinology 143 185-190.

Luo S, Liang Y \& Cincotta AH 1999 Intracebrobrventricular administration of bromocryptine ameliorates the insulin resistant/glucose-intolerant state in hamsters. Neuroendocrinology 69 160-166.

Masuda Y, Tanaka T, Inomata N, Ohnuma N, Tanaka S, Itoh Z, Hosoda H, Kojima M \& Kangawa K 2000 Ghrelin stimulates gastric acid secretion and motility in rats. Biochemical and Biophysical Research Communications 276 905-908.

Nakazato M, Murakami N, Date Y, Kojima M, Matsuo H, Kangawa K \& Matsukura S 2001 A role for ghrelin in the central regulation of feeding. Nature 409 194-198.

Newman RE, McConnell SJ, Weston RH, Reeves M, Bernasconi C, Baker PJ \& Wynn PC 1998 The relationship between plasma testosterone concentrations and the seasonal variation in voluntary feed intake in fallow bucks (Dama dama). Journal of Agricultural Science 130 357-366.

Otto B, Cuntz U, Fruehauf E, Wawarta R, Folwaczny C, Riepl RL, Heiman ML, Lehnert P, Fichter M \& Tschöp M 2001 Weight gain decreases elevated plasma ghrelin concentrations of patients with anorexia nervosa. European Journal of Endocrinology 145 669-673.

Paik KH, Choe YH, Park WH, Oh YJ, Kim AH, Chu SH, Kim SW, Kwon EK, Han SJ, Shon WY et al. 2006 Suppression of acylated ghrelin during oral glucose tolerance test is correlated with whole-body insulin sensitivity in children with Prader-Willi syndrome. Journal of Clinical Endocrinology and Metabolism 91 1876-1881.

Pauly JE \& Scheving LE 1967 Circadian rhythms in blood glucose and the effect of different lighting schedules, hypophysectomy, adrenal medullectomy and starvation. American Journal of Anatomy 120 627-636.

Peeters TL 2005 Ghrelin: a new player in the control of gastrointestinal functions. Gut 54 1638-1649.

Rindi G, Necchi V, Savio A, Torsello A, Zoli M, Locatelli V, Raimondo F, Cocchi D \& Solcia E 2002 Characterization of gastric ghrelin cells in man and other mammals:studies in adult and fetal tissues. Histochemistry and Cell Biology 117 511-519.

Salfen BE, Carroll JA \& Keisler DH 2003 Endocrine reponses to short-term deprivation in weanling pigs. Journal of Endocrinology 178 541-551.

Salfen BE, Carroll JA, Keisler DH \& Strauch TA 2004 Effects of exogenous ghrelin on feed intake, weight gain, behavior, and endocrine responses in weanling pigs. Journal of American Science 82 1957-1966.
Shiiya T, Nakazato M, Mizuta M, Date Y, Mondal MS, Tanaka M, Nozoe S, Hosoda H, Kangawa K \& Matsukura S 2002 Plasma ghrelin levels in lean and obese humans and the effect of glucose on ghrelin secretion. Journal of Clinical Endocrinology and Metabolism 87 240-244.

Shintani M, Ogawa Y, Ebihara K, Aizawa-Abe M, Miyanaga F, Takaya K, Hayashi T, Inoue G, Hosoda K, Kojima M et al. 2001 Ghrelin, an endogenous growth hormone secretagogue, is a novel orexigenic peptide that antagonizes leptin action through the activation of hypothalamic neuropeptide Y/Y1 receptor pathway. Diabetes 50 227-232.

Sugino T, Hasegawa Y, Kikawa Y, Yamaura J, Yamagishi M, Kurose Y, Kojima M, Kangawa K \& Terashima Y 2002 A transient ghrelin surge occurs just before feeding in a scheduled meal-fed sheep. Biochemical and Biophysical Research Communications 295 255-260.

Tomasetto C, Karam SM, Ribieras S, Masson R, Lefebvre O, Staub A, Alexander G, Chernard M-P \& Rio M-C 2000 Identification and characterization of a novel gastric peptide hormone: the motolin-related peptide. Gastroenterology 119 395-405.

Toshinai K, Mondal MS, Nakazato M, Date Y, Murakami N, Kojima M, Kangawa K \& Matsukura S 2001 Upregulation of ghrelin expression in the stomach upon fasting, insulin-induced hypoglycemia, and leptin administration. Biochemical and Biophysical Research Communications 281 1220-1231.

Trumper BG, Reschke K \& Molling J 1995 Circadian variation of insulin requirement in insulin dependent diabetes-mellitus. The relationshipbetween circadian change in insulin demand and diurnal patterns of growth hormone, cortisol and glucagon during euglycemia. Hormone and Metabolic Research 27 141-147.

Tschöp M, Weyer C, Tataranni PA, Devanarayan V, Ravussin E \& Heiman ML 2001 Circulating ghrelin levels are decreased in human obesity. Diabetes $50707-709$.

Wren AM, Small CJ, Ward HL, Murphy KG, Dakin CL, Taheri S, Kennedy AR, Roberts GH, Morgan DGA, Ghatei MA et al. 2000 The novel hypothalamic peptide ghrelin stimulates food intake and growth hormone secretion. Endocrinology 141 4325-4328.

Received in final form 7 April 2008

Accepted 22 April 2008

Made available online as an Accepted Preprint 22 April 2008 